https://doi.org/10.31426/ijamsr.2018.1.10.1019

International Journal of
I J A M S R

\title{
QUALITIES OF EFFECTIVE TEACHERS
}

\author{
Dr. Rayees Ahmad Dar \\ Faculty of Education, Kashmir University,Kashmir, India \\ Email: Rayees78601@gmail.com
}

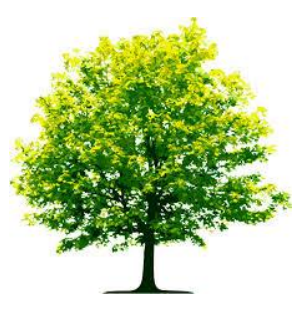

Keywords: Teacher Effectiveness,
Professional $\quad$ commitment,
Classroom $\quad$ teaching,

Encouragement and Punctuality.

\begin{abstract}
A B S T R A C T
A professionally committed teacher educator should possess all the attributes of a professional teacher. As a profession, teaching has been considered as the noblest profession from times immemorial. In this regard the National Policy on Education (1986) has also observed that the status of the teacher reflects the social cultural ethos of a society. Besides, Kothari Commission (1964-1966) has put forth that of all the different factors which influences the quality, competence and character of teacher are undoubtedly, the most significant. This study examined factors promoting teacher effectiveness like professional commitment, punctuality, job satisfaction, attitude towards teaching, appropriate training and good learning environment. The sample for the study consists of 800 secondary school teachers which were collected by random sampling. Professional commitment scale developed by Ravinder Kaur and Sarbjit Kaur was used and Teacher Effectiveness scale developed by Umme Kulsum. The results of the study showed that the effective secondary school teachers have more professional commitment towards their teaching profession. The results also revealed that effective teachers are more committed to their jobs and also show positive commitment both towards students as well as the progressive betterment of society.
\end{abstract}

Citation: Rayees Ahmad Dar (2018). Qualities of Effective Teachers. International Journal of Advanced Multidisciplinary Scientific Research (IJAMSR ) ISSN:2581-4281 Vol 1, Issue 10, December, 2018, \#Art.1019, pp 82-87

\section{Introduction}

Education in the largest sense is an act or an experience that has a formative effect on the mind, character or physical ability of an individual. In its technical sense, education is the process by which society deliberately transmits its accumulated knowledge, skills and values from one generation to another society. Education in real sense is to humanize humanity and to make life progressive cultured and civilized. It is very important for the progress of the individual and society. It is 


\section{International Journal of Advanced Multidisciplinary Scientific Research (IJAMSR) ISSN:2581-4281}

through education that man develops his thinking and reasoning, problem solving, intelligence and creativity and aptitude, positive sentiments and skills, good values and attitudes. Education is a dialogue between the past, present and the future, so that the coming generations receive the accumulated lessons of the heritage and carry it forward (UNESCO, 1998).

A professionally committed teacher educator should possess all the attributes of a professional teacher. As a profession, teaching has been considered as the noblest profession from times immemorial. In this regard the National Policy on Education (1986) has also observed that the status of the teacher reflects the social cultural ethos of a society. Besides, Kothari Commission (19641966) has put forth that of all the different factors which influences the quality, competence and character of teacher are, undoubtedly, the most significant. It is necessary that teachers should be given full support to develop their potential and creative skills so that their teaching be more effective. The teacher acts as a pivot for the transmission of intellectual and technical skills and the cultural traditions from one generation to another. The responsibility of the teacher is very great. Therefore, it is right to say that the nations will depend on the teachers well being. A teacher needs much more than he needs to have the vision of the kind of the society for which he is preparing the students. Every trade or occupation requires certain necessary qualities and qualifications which an individual member of it required to possess. It is an admitted fact that the effective and fruitful teaching depends on the personality of the teacher, which influences the developments of the tuft. It cannot be denied that certain typical divergent characteristics make a person an ideal teacher. Kneller (1968) is of the opinion that of all the people the teacher is the best placed to promote the growth of free and creative mind; in those who came before him aspiring with a passionate concern. His function is to assist each student personally in his journey. Towards self realization, the teacher has the task of stimulating and guiding his child learning so as to assure his attainment of socially approved goals in the most efficient way possible. The job of teacher is more than teaching, it also involves the job of improving the profession and education and there is a third role that he has to play the role as educational leader. This third role for teachers are, perhaps unique among the professions, because the members of no other profession are so intimately involved in lives in almost all the people of the community so involved in the task of economic, political, social, and cultural life as the teacher.

\section{Objectives:}

i. To find out the factors promoting teacher effectiveness.

ii. To suggest the measures for improving the professional commitment, attitude towards teaching and job satisfaction of teachers.

\section{Sample:}

The present study was conducted on 800 secondary school teachers from Kashmir valley (400 male and 400 female). The sample was taken randomly from various higher secondary schools in Kashmir division. After that the investigator employed the Teacher Effectiveness Scale by Umme Kulsum for identifying the effective and less effective secondary school teachers. The upper $27 \%$ of sample as effective and lower $27 \%$ of the sample as less effective teachers. 


\section{International Journal of Advanced Multidisciplinary Scientific Research (IJAMSR) ISSN:2581-4281}

A tool used: The data collected with the help of professional commitment scale developed by Ravinder Kaur and Sarbjit Kaur (2011) and Teacher Effectiveness Scale by Umme Kulsum. The inventory was administered to the sample subjects in the respective institutions in order to collect the data

\section{Statistical treatment:}

The data was analyzed by applying Mean .S.D and't' test of significance.

\section{Statistical Analysis}

Table 1: Showing the Mean and SD comparison between Effective and Less Effective Secondary School Teachers on their various dimensions of professional commitment.

\begin{tabular}{|c|c|c|c|c|c|c|}
\hline $\begin{array}{l}\text { Area/Dimensio } \\
\text { ns }\end{array}$ & $\begin{array}{l}\text { Grou } \\
\text { p }\end{array}$ & $\mathbf{N}$ & Mean & $\begin{array}{l}\text { Std. } \\
\text { Deviatio } \\
\text { n }\end{array}$ & $\begin{array}{l}\text { t- } \\
\text { valu } \\
\text { e }\end{array}$ & $\begin{array}{l}\text { Level of } \\
\text { Significan } \\
\text { ce }\end{array}$ \\
\hline \multirow{2}{*}{$\begin{array}{l}\text { Commitment } \\
\text { to learner }\end{array}$} & ESST & $\begin{array}{l}21 \\
6\end{array}$ & 33.22 & 3.502 & \multirow{2}{*}{$\begin{array}{l}4.36 \\
7\end{array}$} & \multirow{2}{*}{$\begin{array}{l}\text { Significant } \\
\text { at } 0.01 \\
\text { level }\end{array}$} \\
\hline & $\begin{array}{l}\text { LESS } \\
\mathrm{T}\end{array}$ & $\begin{array}{l}21 \\
6\end{array}$ & 31.41 & 5.004 & & \\
\hline \multirow{2}{*}{$\begin{array}{l}\text { Commitment } \\
\text { to society }\end{array}$} & ESST & $\begin{array}{l}21 \\
6\end{array}$ & 32.89 & 3.542 & \multirow{2}{*}{$\begin{array}{l}6.15 \\
4\end{array}$} & \multirow{2}{*}{$\begin{array}{l}\text { Significant } \\
\text { at } 0.01 \\
\text { level }\end{array}$} \\
\hline & $\begin{array}{l}\text { LESS } \\
\mathrm{T}\end{array}$ & $\begin{array}{l}21 \\
6\end{array}$ & 30.48 & 4.529 & & \\
\hline \multirow{2}{*}{$\begin{array}{l}\text { Commitment } \\
\text { to profession }\end{array}$} & ESST & $\begin{array}{l}21 \\
6\end{array}$ & 34.28 & 4.805 & \multirow{2}{*}{$\begin{array}{l}6.77 \\
4\end{array}$} & \multirow[t]{2}{*}{$\begin{array}{l}\text { Significant } \\
\text { at } 0.01 \\
\text { level }\end{array}$} \\
\hline & $\begin{array}{l}\text { LESS } \\
\mathrm{T}\end{array}$ & $\begin{array}{l}21 \\
6\end{array}$ & 31.13 & 4.855 & & \\
\hline
\end{tabular}

\begin{tabular}{|c|c|c|c|c|c|c|}
\hline \multirow{2}{*}{$\begin{array}{l}\text { Commitment } \\
\text { to attain } \\
\text { excellence }\end{array}$} & ESST & $\begin{array}{l}21 \\
6\end{array}$ & 32.76 & 5.140 & \multirow{2}{*}{$\begin{array}{l}2.68 \\
7\end{array}$} & \multirow{2}{*}{\begin{tabular}{ll}
\multicolumn{2}{l|}{ Significant } \\
at & 0.01 \\
level &
\end{tabular}} \\
\hline & $\begin{array}{l}\text { LESS } \\
\mathrm{T}\end{array}$ & $\begin{array}{l}21 \\
6\end{array}$ & 31.29 & 6.198 & & \\
\hline \multirow{2}{*}{$\begin{array}{l}\text { A } \\
\text { commitment } \\
\text { to basic } \\
\text { human values }\end{array}$} & ESST & $\begin{array}{l}21 \\
6\end{array}$ & 32.34 & 4.952 & \multirow{2}{*}{$\begin{array}{l}2.20 \\
8\end{array}$} & Significant \\
\hline & $\begin{array}{l}\text { LESS } \\
\mathrm{T}\end{array}$ & $\begin{array}{l}21 \\
6\end{array}$ & 31.26 & 4.260 & & \\
\hline \multirow{2}{*}{$\begin{array}{l}\text { Overall } \\
\text { professional } \\
\text { commitment }\end{array}$} & ESST & $\begin{array}{l}21 \\
6\end{array}$ & $\begin{array}{l}165.4 \\
9\end{array}$ & 10.881 & \multirow{2}{*}{$\begin{array}{l}7.79 \\
2\end{array}$} & Significant \\
\hline & $\begin{array}{l}\text { LESS } \\
T\end{array}$ & $\begin{array}{l}21 \\
6\end{array}$ & $\begin{array}{l}155.6 \\
7\end{array}$ & 14.998 & & level \\
\hline
\end{tabular}

LESST = Less Effective Secondary School Teachers, ETSST $=$ Effective Secondary School Teachers

\section{Discussion and Interpretation of Results}

While analyzing the mean difference between effective and less effective secondary school teachers on factor (Commitment to Learner) dimension of professional commitment, the results show a clear distinction between the two groups. Effective secondary school teachers are higher on commitment to learner factor of professional commitment. Effective secondary school teachers are reported to have a good level of encouraging power to students, favor the discussions among the learners. The effective teachers are reported to develop the confidence among the students. The effective secondary school teachers develop the psychological insights among the students. The effective teachers remain duty bound for all round development of their students, and are reported to give full attention to the students. The less effective secondary school teachers have low professional committed to learning 


\section{International Journal of Advanced Multidisciplinary Scientific Research (IJAMSR) ISSN:2581-4281}

and are less encouraging to the students, don't create a proper confidence among the students. The less effective teachers don't give equal attention to the students, give less attention to the bright students and ignore the students asking questions.

It is evident from the results that effective and less effective secondary school teachers differ significantly from each other on factor (Commitment to Society) of professional commitment. The results depict that effective secondary school teachers have a high professional commitment to society and contribute to the welfare of the society. The effective teachers contribute to the development and progressive betterment of the society. The effective teachers are professionally committed to their profession and always focus on the individual's growth so that in future they will contribute to the society. Effective teachers are active and always take part in social progress, seminars and workshop. The effective teachers make the students good citizens of the society. The effective teachers remain sensitive to what people think of teachers in the society, don't discriminate the students on the grounds of caste and religion. They are watchful to the happening in their neighborhood and believe that teachers are the agents of social change. The less effective secondary school teachers have low professional commitment to society, not take too much interest in the betterment and progress of the society. Less effective teachers are lazy not taking participation in social activities. Less effective secondary school teachers don't focus on the individual growth, low contributors to the social change and believe that the upliftment of the society is concern of social workers only.
On the comparison between the two groups of factor (Commitment to Profession) dimension of professional commitment, the results justify that effective and less effective secondary school teachers differ significantly. This envisages that effective secondary school teachers have a high professional commitment to profession and always give priority to the student's needs and interests. They fulfill the needs of each individual learner by providing a variety of unique teaching methods and techniques. The effective teachers always strive to motivate and engage students in learning. They advocate for their students to ensure that they are getting everything that they need in order to be a successful educated student. The effective teachers are reported to be an active contributor to the process. They give full priority to their teaching profession. The effective teachers feel upset if anyone speaks ills of the teaching profession. They remain fully committed to their profession and are always ready to work on holidays. The less effective secondary school teachers have low professional commitment to profession don't give priority to their students needs and interests. The less effective secondary teachers are not professionally sound, are reported to have low power of motivation. The less effective teachers find the teaching profession as tiresome due to heavy work load. They find more disadvantages in teaching than advantages and don't remain fully committed to their profession. The effective and less effective secondary school teachers differ significantly in factor (Commitment to Attain Excellence) dimension of professional commitment. The results depict that effective secondary school teachers are higher on the mean score than less effective secondary school teachers. The effective secondary teachers attending the seminars and conferences in order to improve the art of teaching and acquire new 
dimensions of knowledge and experience. They believe that achieving excellence is a journey that never ends. Effective teachers treat teaching as a profession which requires continuous learning. Effective teachers always go through educational journals and magazines to update their knowledge. Effective teachers are in search of new techniques and pedagogical skills to be utilized in teaching learning process. They are always active in their approach and feel that scope of excellence in the field of teaching is vast. The less effective teachers are lacking these above mentioned qualities. While comparing effective and less effective secondary school teachers on factor (Commitment to Basic Human Values) dimension of professional commitment, the results show that there is a significant difference between the two groups. The effective secondary school teachers focus on the truthiness, honesty and goodness of the students. They always try to develop the above qualities in their students. They play role model for their students. They develop the sense of truthfulness and honesty among the students. The effective secondary school teachers develop love, sympathy among the students. The less effective secondary school teachers are lacking these characteristics. The other factors which are related to promoting the effectiveness of teachers are teacher knowledge, enthusiasm and responsibility for learning, classroom activities that encourage learning, assessment activities that encourage learning through experience, effective feedback that establishes the learning procedure in the classroom, effective interaction between teacher and students, creating an environment that respects, encourages and stimulates learning through experiences. There are certain other factors which are related to teacher's affectivity are professional commitment, punctuality, appropriate training and good learning environment.

\section{Conclusion:}

It has been found that there is a significant difference between the effective and less effective secondary school teachers on commitment to learner dimension of professional commitment. Significant difference has been found between the effective and less effective secondary school teachers' commitment to the society dimension of professional commitment. There is a significant difference between the effective and less effective secondary school teachers on commitment to the profession dimension of professional commitment. It has been revealed that there is a significant difference between the effective and less effective secondary school commitment to attain the excellence dimension of professional commitment.

Significant difference has been found between effective and less effective secondary school teachers on commitment to basic human values dimension of professional commitment. A significant difference has been established between the effective and less effective secondary school teachers on overall or a composite score of professional commitment.

\section{Educational Measures}

The present study has a very important educational implications for teachers, teacher trainee, professional institutions, policy planners, administrators and young ones. The findings of this study may be helpful in devising programs for improving the professional commitment, attitude towards teaching and job satisfaction of secondary school teachers in the following way.

Teachers are mainly responsible for all round development of students. They should update themselves 


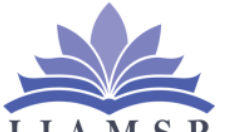

International Journal of

Advanced Multidisciplinary Scientific Research (IJAMSR) ISSN:2581-4281

by learning to deal with many psychological, sociological and educational problems of students with the help of the latest literature and by participating in professional development programs.

Orientation courses/ refresher courses should be organized which help the teachers to excel in their profession.No country can make any progress if teachers are ignored, so teachers must be motivated to have a positive attitude towards their teaching profession. Teacher's attitude towards profession should form one of the important criteria of recruitment procedure for educational institutions, so that teachers with positive professional attitude came forward to deliver effectively. The less effective teachers should be encouraged, so that they work with interest, full intention and zeal. They should be given different prizes to develop the proper attitude towards teaching. The teacher is one of the most important components in the educational process and has a direct bearing on the minds of the students, so helshe should have job satisfaction. Sensitization programs regarding job satisfaction should be organized for the least effective teachers.

References:

1) Armstrong, M. (2006). A Handbook of Human resource Management Practice, Tenth Edition, Koran Page Publishing, London, , p. 264

2) Diuguid, Darraya.R. in( 2009). Studied Student Teachers Awareness, Preparedness and Attitudes of Issues Related to high Poverty Schools. . Journal of Experimental Education June 1955.

3) Christen, M., Ayer, G. and Sober man, D. (2006). Job Satisfaction, Job Performance, and Effort: A Reexamination Using Agency Theory, Journal of Marketing, January, Vol. 70, pp. 137-15

4) Davis, K. and Nostrum, J.W. (1985). Human Behavior at work: Organizational Behavior, 7 editions, McGraw Hill, New York, p.109

5) Herzberg, H. F. (1976). Motivation-Hygiene Profiles, p. 20 George, J.M. and Jones, G.R. (2008). Understanding and Managing Organizational behavior, Fifth Edition, Pearson/Prentice Hall, New Jersey, p. 78

6) Hop pock, R. (1935). Job Satisfaction, Harper and Brothers, New York, p. 47

7) Kaminski, B.S. (2007). Encyclopedia of Business and Finance, Second edition, Thompson Gale, Detroit, $p$. 446

8) Lawler, E.E. III and Porter, L.W. (1967). The Effect of Performance on Job Satisfaction, Industrial Relations, pp. 20-28

9) Locke, E.A. and Latham, G.P. (1990). A theory of goal setting and task performance, Prentice Hall, p.4 Lufthansa, F. (1998). Organizational Behavior, 8 Editions, McGraw-Hill/Irwin, Boston, p. 147

10) Mullins, J.L. (2005). Management and organizational behavior, Seventh Edition, Pearson Education Limited, Essex, p. 700

11) Mrunalini, T. \& Sankaraih. (2010). Study on Attitudes and Reflections of Prospective Teachers on Environmental Concerns. Social psychology of Education, 6, 61-90.

12) Pandey, $R$ and Tripathy,(2006). Attitude towards teaching, Harper and Brothers, New York, p. 47

13) Rue, L.W. and Byers, L. (2003). Management, Skills and Application, 10 ed., McGraw-Hill/Irwin, New York, p. 259

14) Ranu and Nanda (1999) ). A theory of goal setting and task performance, Prentice Hall, p.4

15) Specter, P.E. (1997). Job satisfaction: Application, assessment, causes and consequences, Thousand Oaks, Corsage Publications, Inc Stat, D. (2004). The Rutledge Dictionary of Business Management, Third edition, Rutledge Publishing, Detroit, p. 78

16) Sweeney, P.D. and McFarland, D.B. (2005). Organizational Behavior, Solutions for Management, McGraw-Hill/Irwin, New York. 57

17) Sunitha and Badola, (2010). Study on studied, IGNOU (B.ED.)Teacher Trainees Attitude towards Awareness of the Fundamental Rights of Secondary school Students rights of secondary school students. . Journal of Higher Education Policy Management, vol.21, no.2,pp. 203-214.

18) Selvaraj Gnanaguru, A \& Suresh Kumar, $M$, in (2008). Study on under Achievement of B.Ed Students in Relation to their Home Environment and Attitude towards Teaching. . Journal of Higher Education Policy Management, vol.21, no.2,pp. 203. 214.

19) UNESCO, (1998). World Declaration on Education for All. Adapted by the World conference on Education for All meeting Basic Learning Needs, Published by UNESCO. 